\title{
Aspects of cell production in mantle tissue of Ciona intestinalis L. (Tunicata, Ascidiacea)
}

\author{
Maria Antonietta Di Bella*, Maria Carmela Carbone, Giacomo De Leo \\ Dipartimento di Biopatologia e Metodologie Biomediche, Università degli Studi di Palermo, Via Divisi 83, 90133 Palermo, Italy
}

Received 1 July 2004; revised 10 December 2004; accepted 17 January 2005

\begin{abstract}
Renewal of cell population is needed in the tunic of ascidians, as the tunic cells are involved in many biological functions. Tunic cells are thought to arrive by migrating across the mantle epithelium into the tunic from the blood lacunae or the mesenchymal space. Electron microscope observations show that the mantle epithelium of Ciona intestinalis shares some proliferative characteristics, releasing cells into the tunic and thus providing an increase renewal of tunical cells in restricted zones of adult animals.
\end{abstract}

(C) 2005 Elsevier Ltd. All rights reserved.

Keywords: Ascidians; Ciona intestinalis; Cell proliferation; Comparative immunology

Tunicates, one of the most evolved invertebrata taxa, are marine organisms considered to be primitive chordates (Urochordata) and thus represent a significative animal model for studies on the phylogenetic relationship with vertebrates (Berrill, 1955; Cameron et al., 2000; Dehal et al., 2002).

Tunicates, commonly known as the sea squirt, are characterized by the presence of the tunic, an outer protective specialized tissue, covering the mantle epithelium or epidermis. The tunic consists of a leathery or gelatinous matrix containing microfibrils linked to proteins, and free living cells are randomly distributed within it (De Leo et al., 1977, 1981; Patricolo and De Leo, 1979; Welsch, 1984; Hirose et al., 1994a; Di Bella et al., 1998); these cells are involved in many biological functions such as tunic synthesis, wound healing (Goodbody, 1974; De Leo et al., 1981), immunological and excretory activities (Parrinello and Patricolo, 1984; Parrinello et al., 1984; De Leo, 1992; Hirose et al., 1994b; De Leo et al., 1996, 1997).

\footnotetext{
* Corresponding author. Tel.: + 3991 6554600; fax: + 39916554624 E-mail address: mdibella@unipa.it (M.A. Di Bella).
}

Investigations on the origin and the renewal of tunical and blood cell populations are crucial from the viewpoint of comparative immunology.

Ascidians have long been known for their remarkable capacity to undergo regeneration. Renewal of the cell population has been observed in the epithelium lining the digestive tract, in lymph nodules, and circulating blood cells (Ermak, 1982).

The present ultrastructural observations report for the first time, data on cell proliferation that occurs in some restricted areas of the mantle epithelium of Ciona intestinalis (Ascidiacea).

Adult $C$. intestinalis used for this study, were collected from Palermo harbour. Animal were anaesthetized in MS 222 to obtain the complete relaxation of the animal body, and cubes of tunic fragments, $1-3 \mathrm{~mm}$ long, cut off from the oral siphon, were fixed in $1.5 \%$ glutaraldehyde at $4{ }^{\circ} \mathrm{C}$ for $1 \mathrm{~h}$. The specimens were then subjected to post-fixation in $1 \%$ osmium tetroxide at $4{ }^{\circ} \mathrm{C}$ for $1 \mathrm{~h}$ and dehydrated in a graded series of ethanol solutions, then in propylene oxide and embedded in epon resin. Thin sections stained with uranyl acetate and lead citrate were examined under a transmission electron microscope (Philips CM 10), at $80 \mathrm{kV}$.

The mantle epithelium or epidermis is a monolayer epithelium consisting of flattened cells that are bordered by 


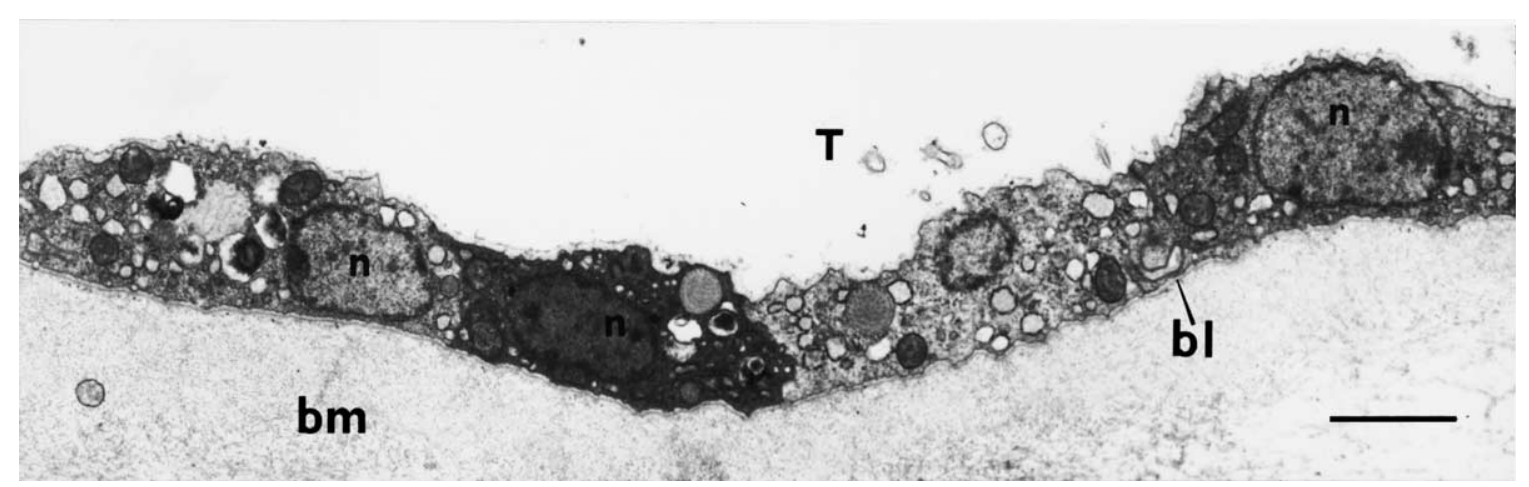

Fig. 1. Micrograph of the mantle epithelium. Cells that show a usual aspect have large, rounded or elongated nuclei (n), prominent nucleoli, mitochondria, and rough endoplasmic reticulum; the large microfibrillar basement membrane (bm) and the smooth basal lamina (bl) are well evident. T, tunic; Scale bar: $2 \mu \mathrm{m}$.

a basal lamina and lined by a thick microfibrillar basement membrane on the surface facing the mesenchimal spaces (Fig. 1). Cells extensively interdigitate and are joined by junctional complexes (Fig. 2). Even if the epithelium is squamous, the cell shape can sometimes diversify in various physiological situations.

Proliferation zones are present in the epithelium of the oral siphon of adult samples; cells are usually arranged in a simple monolayer but as they assume a columnar shape, the layer becomes thicker (Fig. 3a and b). Moreover, epithelial cells are characterized by a large nucleus with a nucleolus, abundant cisternae of RER, some Golgi profiles, and free ribosomes; large cisternae containing electron dense granules are often observed in the cytoplasm and a basal lamina with a basement membrane, rich in microfibrils, underlies the epithelial sheet. The deep cellular interdigitations along the lateral surfaces of cells are not frequent, but an increased number of wider intercellular spaces is seen. As the latter become larger, a discontinuous contact zone appears until cells remain connected by a thin neck (Figs. 3 and 4). These changes lead to the release of the cells into the tunic ground substance when the points of contact with the epithelial cell membrane are lost; several cells are in fact encountered when completely separated from the epithelium both single and in groups (Fig. 3a and b).

From the present observations it is reasonable predict that mantle epithelium has proliferative capabilities, and owing to the activation of proliferation regions, cells detach from it. These cells undergo structural changes as they move towards the tunic.

As regards the origin of tunic cells, several different opinions exist; in general, they are thought to originate from the blood or connective tissue and recent data (Di Bella and De Leo, 2000) have shown in $C$. intestinalis, the migration by diapedesis of cells from the blood lacunae, trough the mantle epithelium, into the tunic and subsequent increase of the cell population.
In $C$. intestinalis, during an induced encapsulation response, small lymph nodules and folding of the endothelial vessels wall in the process of proliferating and extruding cells, were also found (De Leo et al., 1987).

Transdifferentiation of specialized tissues occurs in colonial tunicates during budding; the atrial epithelium has been shown to form the major organ rudiments within a developing bud (Kawamura and Fujiwara, 1995). In this context different interactions are required and regulate the developmental stability and multipotency of the atrial epithelial tissue although it is specialized and composed of pigmented granular cells that usually express a few differentiation markers. Endogenous signals perhaps coming from the mesenchymal cells or from the extracellular matrix might be synthesized to initiate the transdifferentiation of the atrial epithelium.

Even if the context of bud formation of colonial ascidians is very different from that here reported, it can be suggested that factors released elsewhere could promote cell proliferation of the mantle epithelium,

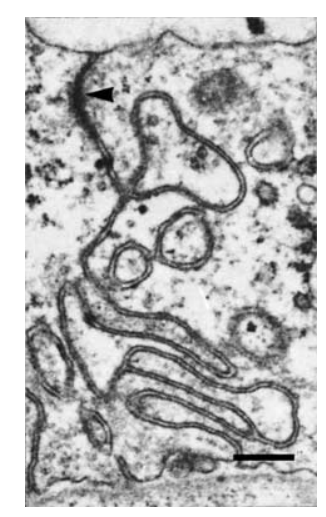

Fig. 2. Detail of the intercellular contacts between lateral plasma membranes of epithelial cells: they are very convoluted and electron dense junctions are present (arrow head); Scale bar: $0.5 \mu \mathrm{m}$. 

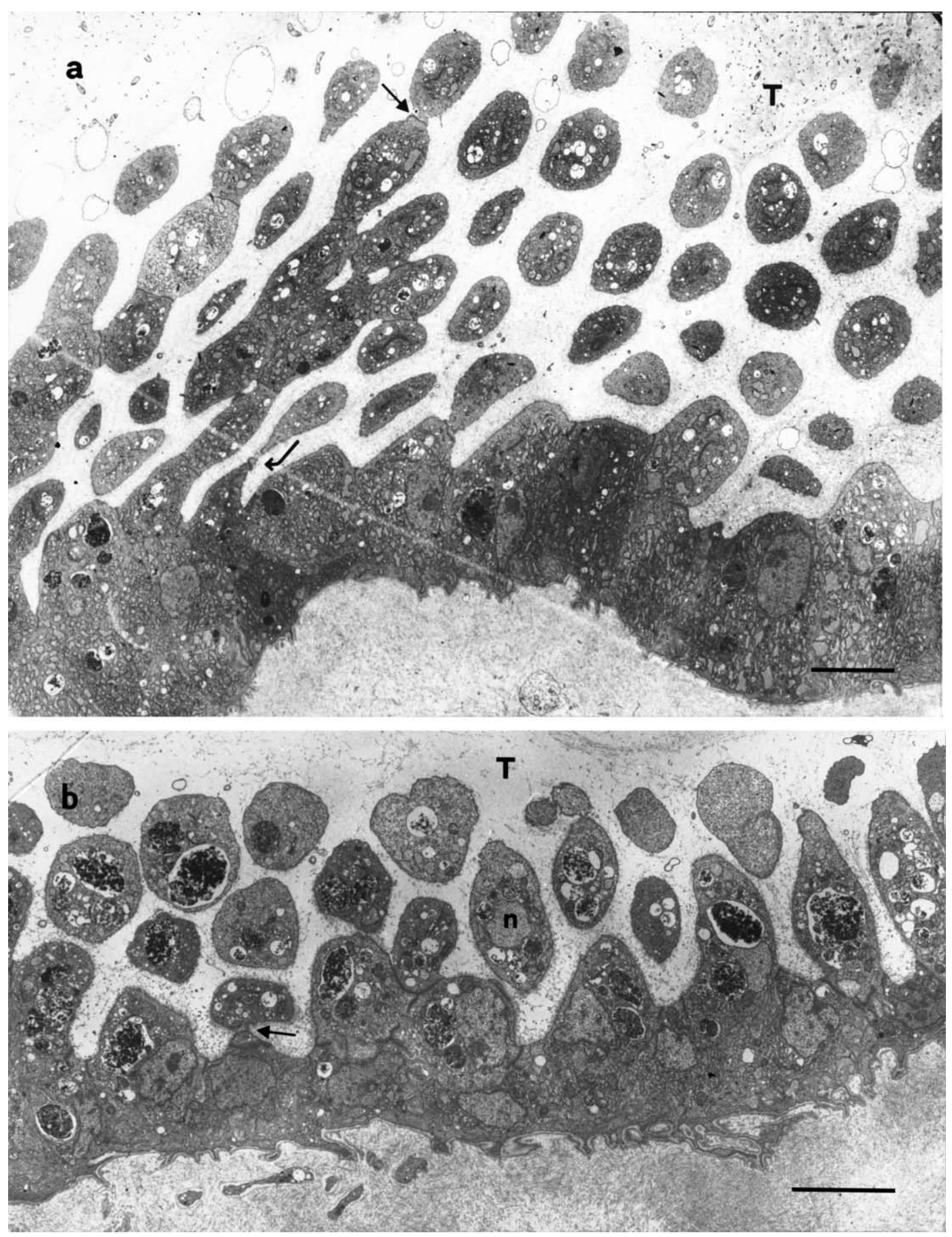

Fig. 3. Electron micrographs of the mantle budding zone (a and b). Columnar-shaped epithelial cells are present. Cells contain a large nucleus (n) and a single nucleolus. A coat of fibrogranular material lines the tunic side of the epithelium. Several cells in the process of leaving the epithelium are present, so that the contact surfaces between them and the epithelium are restricted to narrow necks (arrows). Other cells are free in the tunic; Scale bars: $5 \mu \mathrm{m}$.

destabilizing its differentiation state. Perhaps signals coming from the tunic itself may play a role in the process of calling circulating haemocytes from the blood lacunae and/or act on the mantle epithelium to alter the stability.

In conclusion, collaboration between the cells from the mantle epithelium and the blood cells is probably needed for the renewal of tunic cell population in some areas of the animal body.

Our finding thus suggests a question: may the developmental flexibility of differentiated epithelia be a general feature of ascidians?

Further investigations are therefore needed to understand the role of epithelial cells in morphogenesis and tissue 

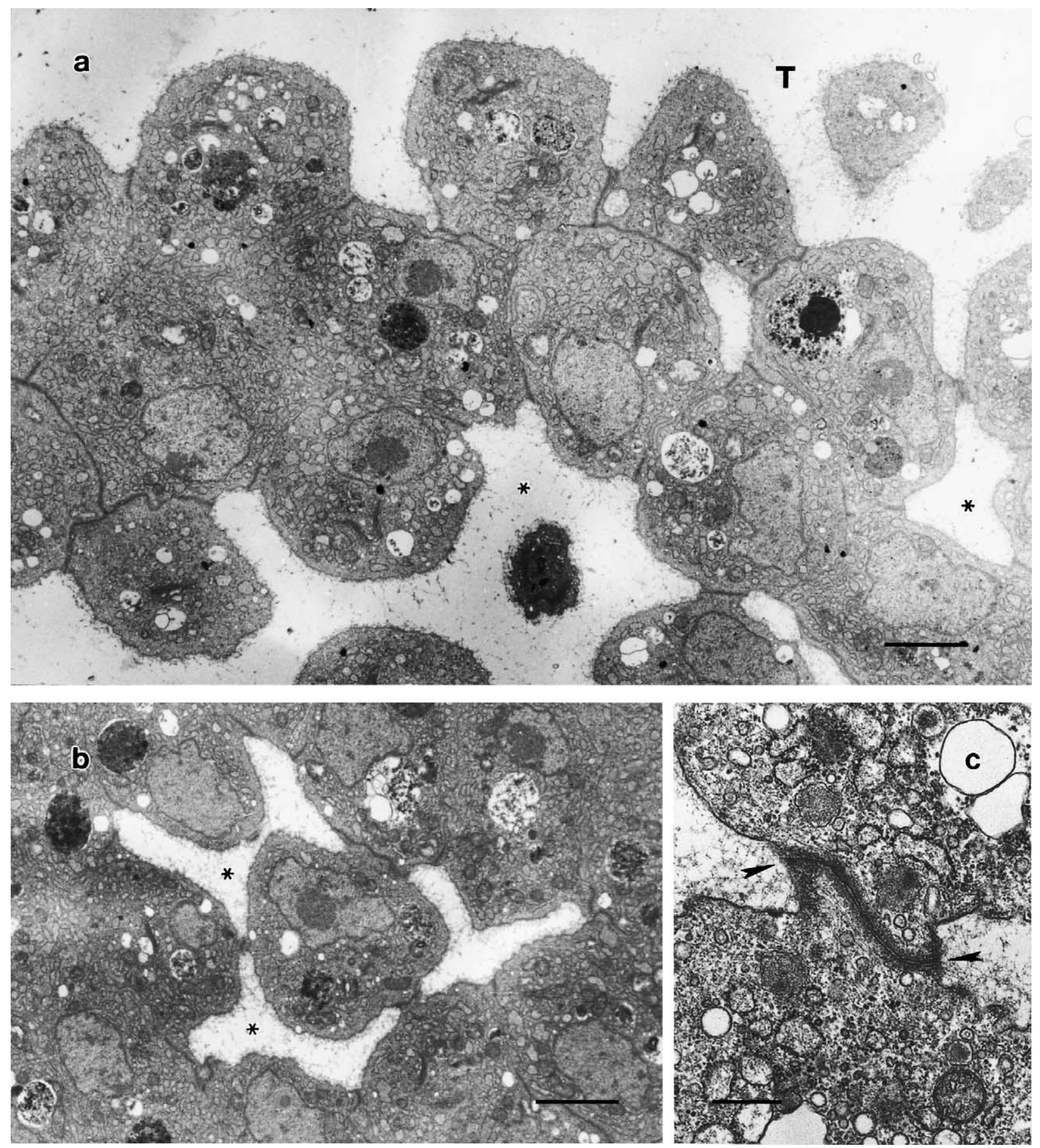

Fig. 4. Mantle budding zone were intercellular contact between lateral plasma membranes of the epithelial cells are partially lost (a and b). Note the extensive intercellular spaces (*) and electron-dense cells contacts. Scale bar: $2.5 \mu \mathrm{m}$. (c) shows an enlarged detail of the restricted contact between two cells (arrows). Scale bar: $0.5 \mu \mathrm{m}$; $\mathrm{T}$, tunic.

regeneration and, the potential involvement of factors and stimuli that induce blood cells to infiltrate into the tunic and/or epithelial cells to proliferate.

\section{Acknowledgements}

This investigation was partially supported by the Italian Ministero della Istruzione, Università e Ricerca Scientifica.

\section{References}

Berrill, N.J., 1955. The Origin of Vertebrates. Clarendon Press, Oxford. Cameron, C.B., Garey, J.R., Swalla, B.J., 2000. Evolution of the chordates body plan: new insights from phylogenetic analyses of deuterostome phyla. Proc. Natl. Acad. Sci. USA 97, 4469-4474.

Dehal, P., Satou, R., Campbell, J., Chapman, J., Degnan, B., De Tomaso, A., Davidson, B., Di Gregorio, A., Gelpke, M., Goodstein, D., Harafuji, N., Hastings, K.E., Ho, I., Hotta, K., 
Huang, W., Kawashima, L.T., Lemaire, P., Martinez, D., Meinertzhagen, I.A., Necula, S., Nonaka, M., Putnan, N., Rash, S., Saiga, H., Satake, M., Terry, A., Yamada, L., Wang, H-G., Awazu, S., Azumi, K., Boore, J., Lbranno, M., Chin-bow, S., De Santis, R., Doyle, S., Francino, P., Keys, D.N., Haga, S., Hayashi, M., Hino, K., Imai, K.S., Inaba, K., Kano, S., Kobayashi, K., Kobayashi, M., Lee, B., Makabe, K.W., Manohar, C., Matassi, G., Medina, M., Mochizuki, Y., Mount, S., Morishita, T., Miura, S., Nakayama, A., Nishizaka, S., Nomoto, H., Ohta, F., Oishi, K., Rigoutsos, I., Sano, M., Sasaki, A., Sasakura, Y., Shoguchi, E., Shin-I, T., Spagnuolo, A., Stainer, D., Suzuki, M.M., Tassy, O., Takatori, N., Tokuoka, M., Yagi, K., Yoshizaki, F., Wada, S., Zhang, C., Hyatt, P.D., Larimer, F., Detter, C., Doggett, N., Glavina, T., Hawkins, T., Richardson, P., Lucas, S., Kohara, Y., Levine, M., Satoh, N., Rokhsar, D.S., 2002. The draft genome of Ciona intestinalis: insights into chordate and vertebrate origins. Science 298, 2157-2167.

De Leo, G., 1992. Ascidian hemocytes and their involvement in defence reactions. Boll. Zool. 59, 195-213.

De Leo, G., Patricolo, E., D’Ancona Lunetta, G., 1977. Studies on the fibrous components of the test of Ciona intestinalis Linnaeus. I. Cellulose-like polysaccharide. Acta Zool. (Stockh.) 58, $135-141$.

De Leo, G., Patricolo, E., Frittitta, G., 1981. Fine structure of the tunic of Ciona intestinalis L. II. Tunic morphology, cell distribution and their functional importance. Acta Zool. (Stockh.) 62, 259-271.

De Leo, G., Parrinello, N., Di Bella, M.A., 1987. Fine structure of blood system in Ciona intestinalis L. (Tunicata). Vessels and hemocytes in pharyngeal wall. Arch. Biol. (Bruxelles) 98, 35-52.

De Leo, G., Parrinello, N., Parrinello, D., Cassarà, G., Di Bella, M.A., 1996. Encapsulation response of Ciona intestinalis (Ascidiacea) to intratunical erythrocyte injection. I. The inner capsular architecture. J. Invert. Pathol. 67, 205-212.

De Leo, G., Parrinello, N., Parrinello, D., Cassarà, G., Russo, D., Di Bella, M.A., 1997. Encapsulation response of Ciona intestinalis
(Ascidiacea) to intratunical erythrocyte injection. II. The outermost inflamed area. J. Invert. Pathol. 69, 14-23.

Di Bella, M.A., De Leo, G., 2000. Hemocyte migration during inflammatory-like reaction of Ciona intestinalis (Tunicata, Ascidiacea). J. Invertebr. Pathol. 76, 105-111.

Di Bella, M.A., Cassarà, G., Russo, D., De Leo, G., 1998. Cellular components and tunic architecture of the solitary ascidian Styela canopus (Stolidobranchiata, Styelidae). Tissue Cell 30, 352-359.

Ermak, T.H., 1982. The renewing cell populations of ascidians. Am. Zool. 22, 795-805.

Goodbody, I., 1974. The physiology of ascidians. In: Russel, F.S., Yonge, M. (Eds.), Advances in Marine Biology, Vol. 12. Academic Press, London, New York, pp. 1-149.

Hirose, E., Nishikawa, T., Saito, Y., Taneda, Y., 1994a. Seven types of tunic cells in the colonial ascidian Aplidium yamazii (Policlinidae, Aplousobranchia): morphology, classification, and possible functions. Zool. Sci. 11, 737-743.

Hirose, E., Ishii, T., Saito, Y., Taneda, Y., 1994b. Phagocitic activity of tunic cells in the colonial ascidian Aplidium yamazii (Policlinidae, Aplousobranchia). Zool. Sci. 11, 203-208.

Kawamura, K., Fujiwara, S., 1995. Cellular and molecular characterization of transdifferentiation in the process of morphallaxis of budding tunicates. Semin. Cell Biol. 6, 117-126.

Parrinello, N., Patricolo, E., 1984. Inflammatory-like reaction in the tunic of Ciona intestinalis (Tunicata). II. Capsule components. Biol. Bull. 167, 238-250.

Parrinello, N., Patricolo, E., Canicattì, C., 1984. Inflammatory-like reaction in the tunic of Ciona intestinalis (Tunicata). I. Encapsulation and tissue injury. Biol. Bull. 167, 229-237.

Patricolo, E., De Leo, G., 1979. Studies on the fibrous components of the test of Ciona intestinalis Linnaeus. II. Collagen-elastin-like protein. Acta Zool. (Stockh.) 60, 259-269.

Welsch, U., 1984. Urochordata. In: Bereiter-Hahn, J., Matoltsy, A.G., Richards, K.S. (Eds.), Biology of the Integument, Invertebrates, Vol. 1. Springer, Berlin, pp. 800-816. 